\title{
Prevalence of female genital mutilation among school girls in El- Mansoura Center, El-Dakahlia Governorate, Egypt
}

\author{
Yasser A. Yasein \\ Public Health and Community Medicine Department, Faculty of Medicine, Al-Azhar University,Egypt.
}

\begin{abstract}
:
Background: Female genital mutilation, has received growing attention from governmental, international organizations and researchers over the last decades due to its impact on women's health.

Objectives: To estimate; the prevalence, some socio-demographic determinants and post-practice complication associated with FGM among secondary school girls in El-Mansoura Center, El-Dakahlia Governorate, Egypt

Subjects \& Methods: A cross-sectional study conducted during the year 2013. Total number of girls included in the study were 721 (369 from urban areas and 352 from the rural areas), with mean age of 16.29 1.53 years. The questionnaire was filled by the participants themselves over a period of one month (through February 2013).

Results: The prevalence of FGMwas $53.7 \%$. In the rural areas the prevalence was (65.6\%), compared to (42.3\%) in the urban areas. Factors associated with FGM included; rural residence $(P<0.05)$, lower educational levels of the both parents $(P<0.05)$, and those living in lowest economic levels $(P<0.05)$. The procedure was predominantly performed by a physician in the urban area $(71.8 \%)$, compared to $(59.3 .5 \%)$ in the rural areas. The mothers were the main decision-makers for the procedure of FGM. More than one half of respondents $(55.1 \%)$ were against continuation of the practice. The most common reasons under continuation of the practice were; religious requirement (32.1\%), cultural and social traditional (23.1\%), restraining sexual desire (17.0\%), cleanliness for girls (12.3\%), chastity (9.0\%) and evidence of feminist (6.5\%). The most common post-practice complication were; bleeding (30.5\%), infection (27.4\%), pain (20.4\%), shock (12.9\%) and injury to adjacent tissues $(8.8 \%)$.

Conclusion: FGM is widespread among school girls in Egypt. Factors associated with FGM included; rural residence, lower educational levels of the both parents, and those living in lowest economic levels. The medical physicians were the main performers ofFGM. There was a considerable support for the continuation of the practice particularly in the rural areas.
\end{abstract}

Keywords: FGM, secondary school girls, prevalence, health consequences.

\section{Introduction}

Female genital mutilation (FGM), has received growing attention from governmental and international organizations and researchers over the last decadesdue to its impact on women's health ${ }^{(1,2)}$.

Despite the efforts combating this practice, still millions of women worldwide are affected. The World Health Organization estimates that between 100 million and 140 million girls and women worldwide have undergone some type of circumcision, and currently about 3 million girls, most of them under 15 years of age, undergo the procedure every year. The great majority of affected women live in 28 countries in Africa, but the practice has also been reported in parts of the Middle East, Asia, and Latin America. Countries on the African continent with the highest prevalence of female circumcision are Djibouti, Egypt, Eritrea, Ethiopia, Gambia, Guinea, Mali, Sierra Leone, Somalia, and $\operatorname{Sudan}^{(3,4)}$.

WHO and other United Nations Organizations classified FGM into four types: type 1, also known as clitoridectomy or Suna: involves partial or total removal of the clitoris and/or prepuce; type 2: involves partial or total removal of the clitoris and labia minora, with or without excision of the labia majora; type 3: also known as infibulation or pharaonic, it entails removing part or all of the external genitalia and narrowing the vaginal orifice by re-approximating the labia minora and/or labia majora; type 4: includes any form of other harm done to the female genitalia by pricking, piercing, cutting, scraping or burning ${ }^{(3)}$. The minor form of FGM is when the clitoris is removed. The most severe form of FGM is when all external genitalia are removed and the vaginal opening is stitched nearly closed, and only a small opening is left for urine and menstrual blood ${ }^{(4)}$.

Female circumcision is practiced by people from all educational levels and social classes, including urban and rural residents, and different religious and ethnic groups. The age at which female circumcision is performed varies with local traditions and circumstances, and is reported to be decreasing in some countries, it is generally practiced on girls between the ages of 4 and 10 years, although in some communities it is performed shortly after birth, during adolescence, just before marriage, during first pregnancy, or after the first birth ${ }^{(5,6)}$. 
In Egypt, FGM is deeply rooted culturally as it is believed necessary to moderate female sexuality and guarantee virginity at marriage and marital faithfulness ${ }^{(7)}$.The overall prevalence rate of FGM was $50.3 \%$ among girls in the age group $10-18$ years. The prevalence rate was $61.7 \%$ in the rural schools compared to $46.2 \%$ in urban ones ${ }^{(8)}$.FGM is commonly performed prior to or around puberty and the most common forms in Egypt are type I and type II, while other forms as type III are much less commonly found ${ }^{(9)}$.

The attitudes reflected underlying reasons related to the practice includes; traditional beliefs followed by religious considerations, chastity, honor and lower education ${ }^{(10,11)}$.

FGM can cause a range of health problems, including: bleeding, infection, pain, problems with urination, problems with sex, problems getting pregnant, problems during pregnancy and delivery, increased risk of HIV infection, and psychological and emotional stress ${ }^{(12,13)}$.

Over the past 30 years, the national and international organizations have actively worked on eradicating this practice ${ }^{(5,14)}$.In December 1997, the Court of Cassation in Egypt upheld a government ban on the practice of female circumcision. Issued as a decree by the Minister of health in 1996, the ban prohibits all medical and nonmedical practitioners from performing FGM in either public or private facilities, except for medical reasons certified by the head of a hospital's obstetric department. Perpetrators are subject to the loss of their medical licenses and can be subjected to criminal punishments. In cases of death, perpetrators are also subject to charges of manslaughter under the Penal Code ${ }^{(15)}$.

The current study was conducted to estimate; the prevalence, some socio-demographic determinants and post-practice complication associated with FGM among secondary school girls in El-Mansoura Center, ElDakahlia Governorate, Egypt

\section{Rationale}

The majority of existing research on FGM concentrated on married women in the reproductive age group. As to our knowledge, little is known about the prevalence of FGM among school girls. Such information would be useful to plan appropriate interventions and advocacy activities aiming to eradicate FGM $^{(8,15)}$.

\section{Subjects and Methods}

Study design: A cross-sectional school based survey was conducted on the governmental secondary school girls in El-Mansoura Center, El-Dakahlia Governorate, Egypt

Sample Setting\& inclusion criteria:The current study was conducted in El-Mansoura Center, El-Dakahlia Governorate, Egypt. El-Mansoura Center was chosen for the study due to the following reasons; ease of obtaining approvals from the relevant authorities to conduct the study and ease of transportation. The secondary schools for girls were only included in the study, while all mixed schools (contains both girls and boys) were excluded. The urban area has (12) secondary schools for girls, while the rural area has only (6) schools

Study Sample: five schools were chosen by simple random sampling technique and included in the study (3 schools from the urban area and 2 from the rural). The study was covered all grades (grade 1, $2 \& 3$ ). All girls in the selected schools were submitted in the study with nearly response rate 55\%. The total number of girls included in the study were 721 (369 from the urban area and 352 from the rural area).

Data collection: The questionnaire used in the study was adapted from Egypt Demographic Health Survey $(2008)^{(9)}$. The English version of the questionnaire was translated into Arabic language by specialist professional translator and validity of the questionnaire are granulated by translated the Arabic version again to English language by independent translators for consistency of the translation. The questionnaire was tested on 20 girls as a pilot study in order to evaluate the internal consistency and to determine the time needed to fill the questionnaire. The questionnaire included data regarding; educational level of both parents, persons performing the FGM, place at which the FGM is performed, age at the time of FGM, attitude toward FGM as well as the reasons against and supported continuation of the practice. Training for one day was conducted for ( 2 girls) on; distribution and collection of questionnaire from the selected schools and to answer any questions related to the study. Field survey was conducted after obtaining approval from El- Mansoura Educational Directorate and from all schools chosen for the study. Informed consent from every participant guardian was obtained with nearly response rate 55\%. All girls in the selected schools were exposed to a brief orientation on the purpose of the study and variables included in the questionnaire and how to fill it?. The questionnaire was filled by the participants themselves under supervision of data collector over a period of one month (through February 2013). The field work took two days /weeks with an average number of 90-100 girls per day. In order to ensure the privacy and confidentiality, data were collected anonymously and in special closed place. The socioeconomic status was assessed using Fahmy and El-Sherbini scale ${ }^{(16)}$ (Low $<17$, Moderate 17-25 and High 26-34).

Data analysis: Data were entered, organized, tabulated and analyzed using the standard computer program SPSS (Statistical Package for the Social Sciences) version 19. Quantitative data were expressed as Mean \pm SD, while Qualitative data were expressed as frequency and percent. Student $t$-test was used to measure the 
difference between means of two quantitative groups, while Chi square $\left(\chi^{2}\right)$ was used assess the relationship between two qualitative variables, with the significant level set at 0.05

The term of female genital mutilation (FGM) refers to all procedures involving partial or total removal of the external female genitalia, or other injury to the female genital organs for non-medical reasons ${ }^{(3)}$.

\section{Results}

The current study included (721) school girls, 369 from the urban area and 352 from the rural area with a mean age of $16.29 \pm 1.53$ years. The prevalence of FGM among schoolgirls was $53.7 \%$.

The results of the current revealed that, the prevalence of FGM was significantly higher among rural residency (65.6\%) than in the urban ones $(42.3 \%)$. Educational levels of girl's mother and father were negatively associated with FGM $(P<0.05)$. The prevalence of FGM was commonly observed among girls living at lowest and middle economic levels $(59.6 \%$ and $51.7 \%$, respectively), compared to $(48.9 \%)$ among those living at higher levels, table 2.

The mean age at which the procedure of FGM was performed was significantly lower among rural residents $(8.52 \pm 2.33)$, than urban residents $(9.37 \pm 2.38)$. The procedure was predominantly performed by a physician in the urban area (71.8\%), compared to (59.3.5\%) in the rural areas. On the other hand, the nurses and dayas were performed $(23.1 \%)$ and $(5.1 \%)$ of FGM respectively in the urban areas, compared to $(32.9 \%)$ and $7.8 \%$ in the rural areas. Regarding the place, the findings revealed that, the FGM procedure was commonly performed at home (64.9\%), and there were no statistically significant differences between rural and urban localities $(P>0.05)$

More than three quarters of circumcised girls $(84.8 \%)$ in the rural areas were not submitted to medical examination before the procedure to find out if the girl was in need of circumcision or not, compared to $(67.3 \%)$ in the rural areas, with statistically significant difference $(P<0.05)$. Mothers were the main decision-makers for the procedure of FGM and represented (63.6\%) in the rural area compared to (61.5\%) in the urban area, table 2.

Regarding attitude toward continuation of the practice, more than half of respondents in the urban area $(64.8 \%)$ were against continuation of the practice, compared to $(44.9 \%)$ in the rural area, table 3 .

The results revealed that, the most common reasons against continuation of practice were; no religious support $(31.2 \%)$, painful and unhealthy procedure $(22.9 \%)$, unnecessary for girl $(19.4 \%)$, bad social habit $(16.4 \%)$ and health consequences related to it $(10.1 \%)$. There were no statistically significant differences between rural and urban localities $(\mathrm{P}>0.05)$, table 4 .

The most common reasons under continuation of the practice were; religious requirement $(32.1 \%)$, cultural and social traditional (23.1\%), restraining sexual desire (17.0\%), cleanliness for girls (12.3\%), chastity $(9.0 \%)$ and evidence of feminist $(6.5 \%)$. There were no statistically significant differences between both localities $(\mathrm{P}>0.05)$, table 5 .

The most common post-practice complication were; bleeding (30.5\%), infection (27.4\%), pain (20.4\%), shock $(12.9 \%)$ and injury to adjacent tissues $(8.8 \%)$. There were statistically significant differences regarding the persons performed the FGM $(\mathrm{P}<0.05)$, table 6 .

Table (1) Distribution of studied sample according to general characteristics

\begin{tabular}{|c|c|c|c|c|c|c|c|c|c|}
\hline \multirow{3}{*}{\multicolumn{2}{|c|}{ General characteristics }} & \multicolumn{4}{|c|}{ Studied sample } & \multirow{3}{*}{$\begin{array}{c}\text { Total } \\
(\mathrm{n} .=721 \\
)\end{array}$} & \multirow{3}{*}{$\chi^{2}$} & \multirow{3}{*}{$P$ value } & \multirow{3}{*}{ df } \\
\hline & & \multicolumn{2}{|c|}{$\begin{array}{c}\text { Submitted to } \\
\text { FGM } \\
(\mathrm{n} .=387) \\
\end{array}$} & \multicolumn{2}{|c|}{$\begin{array}{c}\text { Not } \\
\text { submitted } \\
(\mathrm{n} .=334)\end{array}$} & & & & \\
\hline & & No. & $\%$ & No. & $\%$ & & & & \\
\hline \multirow{3}{*}{\multicolumn{2}{|c|}{ Age of the respondents (years) }} & \multicolumn{2}{|c|}{ Mean \pm SD } & \multicolumn{2}{|c|}{ Mean $\pm \mathrm{SD}$} & & & & \\
\hline & & \multicolumn{2}{|c|}{$16.28 \pm 1.53$} & \multicolumn{2}{|c|}{$16.31 \pm 1.54$} & & & & \\
\hline & & \multicolumn{2}{|c|}{$t=.894$} & \multicolumn{2}{|c|}{$\mathrm{P}>0.05$} & & & & \\
\hline \multirow[t]{2}{*}{ Residence } & Urban & 156 & 42.3 & 213 & 57.7 & 369 & \multirow{2}{*}{$39.50 *$} & \multirow{2}{*}{$<0.05$} & \multirow{2}{*}{1} \\
\hline & Rural & 231 & 65.6 & 121 & 34.4 & 352 & & & \\
\hline \multirow{5}{*}{$\begin{array}{l}\text { Educational levels of } \\
\text { father's }\end{array}$} & Illiterate & 75 & 83.3 & 15 & 16.7 & 90 & \multirow{5}{*}{$78.79 *$} & \multirow{5}{*}{$<0.05$} & \multirow{5}{*}{4} \\
\hline & Primary & 50 & 75.8 & 16 & 24.2 & 66 & & & \\
\hline & Preparatory & 47 & 72.3 & 18 & 27.7 & 65 & & & \\
\hline & Secondary & 85 & 47.2 & 95 & 52.8 & 180 & & & \\
\hline & Higher & 130 & 40.6 & 190 & 59.4 & 320 & & & \\
\hline \multirow{5}{*}{$\begin{array}{l}\text { Educational levels of } \\
\text { mother's }\end{array}$} & Illiterate & 51 & 72.9 & 19 & 27.1 & 70 & \multirow{5}{*}{$18.92 *$} & \multirow{5}{*}{$<0.05$} & \multirow{5}{*}{4} \\
\hline & Primary & 37 & 64.9 & 20 & 35.1 & 57 & & & \\
\hline & Preparatory & 31 & 62.0 & 19 & 38.0 & 50 & & & \\
\hline & Secondary & 149 & 49.5 & 152 & 50.5 & 301 & & & \\
\hline & Higher & 119 & 49.0 & 124 & 51.0 & 243 & & & \\
\hline
\end{tabular}


Prevalence of female genital mutilation among school girls in El-Mansoura Center, El-Dakahlia

\begin{tabular}{|l|l|c|c|c|c|c|c|c|c|}
\hline Economic level & Low & 165 & 59.6 & 112 & 40.4 & 277 & \multirow{3}{*}{$6.62 *$} & \multirow{3}{*}{$<0.05$} & \\
\cline { 2 - 10 } & Middle & 92 & 51.7 & 86 & 48.3 & 178 & \multirow{2}{*}{} \\
\cline { 2 - 8 } & High & 130 & 48.9 & 136 & 51.1 & 266 & & & \\
\hline
\end{tabular}

* Statistically significant difference.

Table (2) Distribution of circumcised girls according to situation at which the practice has been performed

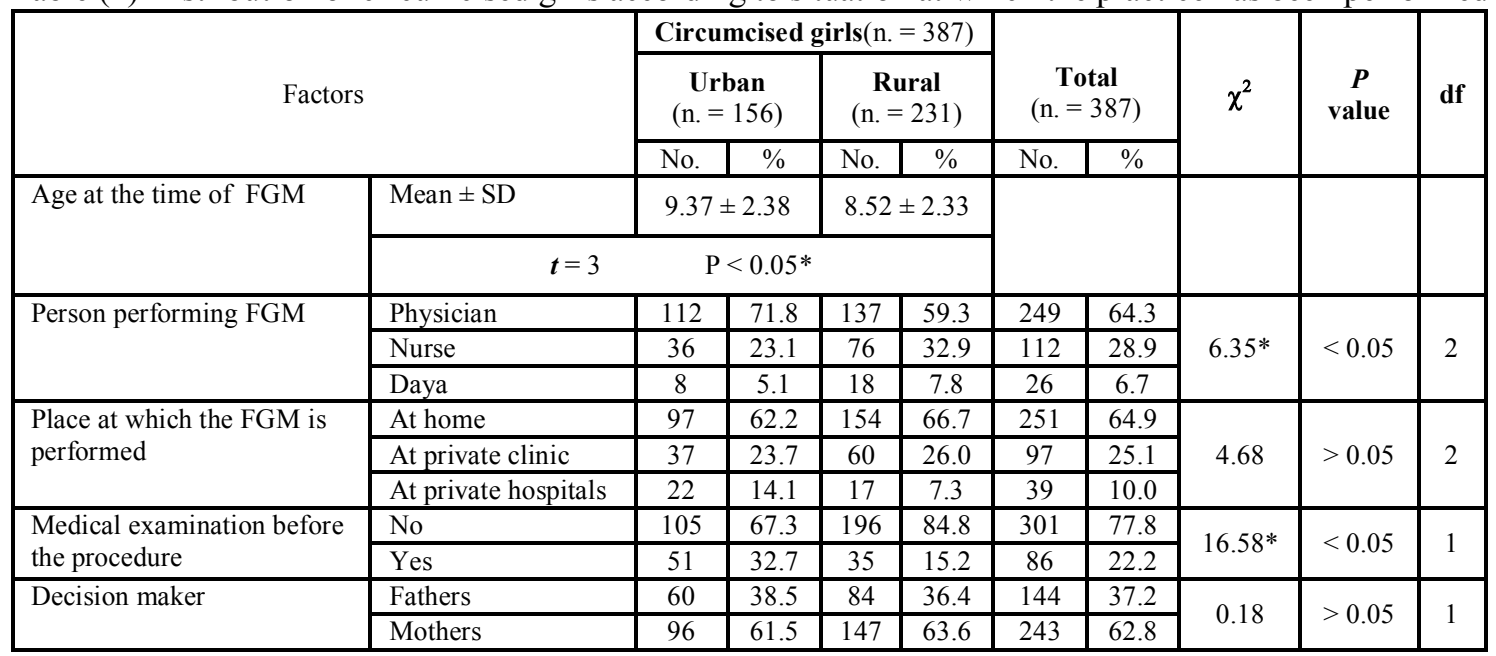

* Statistically significant difference.

Table (3) Distribution of studied sample according to attitude toward FGM

\begin{tabular}{|c|c|c|c|c|c|c|c|c|c|}
\hline \multirow{3}{*}{ Attitude } & \multicolumn{4}{|c|}{ Studied sample } & \multirow{2}{*}{\multicolumn{2}{|c|}{$\begin{array}{c}\text { Total } \\
(\mathrm{n} .=721)\end{array}$}} & \multirow{3}{*}{$\chi^{2}$} & \multirow{3}{*}{$P$ value } & \multirow{3}{*}{ df } \\
\hline & \multicolumn{2}{|c|}{$\begin{array}{c}\text { Urban } \\
(\mathrm{n} .=369) \\
\end{array}$} & \multicolumn{2}{|c|}{$\begin{array}{c}\text { Rural } \\
(\mathrm{n} .=352)\end{array}$} & & & & & \\
\hline & No. & $\%$ & No. & $\%$ & No. & $\%$ & & & \\
\hline Negative & 239 & 64.8 & 158 & 44.9 & 397 & 55.1 & & & \\
\hline Positive & 130 & 35.2 & 194 & 55.1 & 324 & 44.9 & $28.78^{*}$ & 0.05 & 1 \\
\hline
\end{tabular}

* Statistically significant difference.

Table (4) Distribution of respondents with negative attitude according to the residence

\begin{tabular}{|c|c|c|c|c|c|c|c|c|c|}
\hline \multirow{3}{*}{ Reasons of negative attitude } & \multicolumn{4}{|c|}{$\begin{array}{c}\text { Respondents with negative } \\
\text { attitude } \\
\end{array}$} & & & \multirow{3}{*}{$\chi^{2}$} & \multirow{3}{*}{$P$ value } & \multirow{3}{*}{ df } \\
\hline & \multicolumn{2}{|c|}{$\begin{array}{c}\text { Urban } \\
(\text { n. }=239)\end{array}$} & \multicolumn{2}{|c|}{$\begin{array}{c}\text { Rural } \\
(\mathrm{n} .=158)\end{array}$} & \multicolumn{2}{|c|}{$\begin{array}{c}\text { Total } \\
(\mathrm{n} .=397)\end{array}$} & & & \\
\hline & No. & $\%$ & No. & $\%$ & No. & $\%$ & & & \\
\hline No religious support & 75 & 31.4 & 49 & 31.0 & 124 & 31.2 & \multirow{5}{*}{0.97} & \multirow{5}{*}{$>0.05$} & \multirow{5}{*}{4} \\
\hline Painful and unhealthy procedure & 53 & 22.2 & 38 & 24.0 & 91 & 22.9 & & & \\
\hline Unnecessary for girl & 48 & 20.0 & 29 & 18.4 & 77 & 19.4 & & & \\
\hline Bad social habit & 41 & 17.2 & 24 & 15.2 & 65 & 16.4 & & & \\
\hline Health consequences & 22 & 9.2 & 18 & 11.4 & 40 & 10.1 & & & \\
\hline
\end{tabular}

Table (5) Distribution of respondents with positive attitude according to the residence

\begin{tabular}{|c|c|c|c|c|c|c|c|c|c|}
\hline \multirow{3}{*}{ Reasons of positive attitude } & \multicolumn{4}{|c|}{$\begin{array}{c}\text { Respondents with positive } \\
\text { attitude }\end{array}$} & \multirow{2}{*}{\multicolumn{2}{|c|}{$\begin{array}{c}\text { Total } \\
(\mathrm{n} .=324)\end{array}$}} & \multirow{3}{*}{$\chi^{2}$} & \multirow{3}{*}{$P$ value } & \multirow{3}{*}{ df } \\
\hline & \multicolumn{2}{|c|}{$\begin{array}{c}\text { Urban } \\
(\mathrm{n} .=130)\end{array}$} & \multicolumn{2}{|c|}{$\begin{array}{c}\text { Rural } \\
(\mathrm{n} .=194)\end{array}$} & & & & & \\
\hline & No. & $\%$ & No. & $\%$ & No. & $\%$ & & & \\
\hline Religious requirement & 40 & 30.8 & 64 & 33.0 & 104 & 32.1 & \multirow{6}{*}{0.56} & \multirow{6}{*}{$>0.05$} & \multirow{6}{*}{5} \\
\hline Cultural and social traditional & 32 & 24.6 & 43 & 22.2 & 75 & 23.1 & & & \\
\hline Restraining sexual desire & 21 & 16.2 & 34 & 17.5 & 55 & 17.0 & & & \\
\hline Cleanliness for girls & 17 & 13.1 & 23 & 11.9 & 40 & 12.3 & & & \\
\hline Chastity & 12 & 9.2 & 17 & 8.7 & 29 & 9.0 & & & \\
\hline Evidence of feminist & 8 & 6.1 & 13 & 6.7 & 21 & 6.5 & & & \\
\hline
\end{tabular}


Prevalence of female genital mutilation among school girls in El-Mansoura Center, El-Dakahlia

Table (6) Distribution of post practice complications by the person performed the practice.

\begin{tabular}{|c|c|c|c|c|c|c|c|c|c|}
\hline \multirow{3}{*}{ Health consequences } & \multicolumn{4}{|c|}{ Person performed the practice } & \multirow{2}{*}{\multicolumn{2}{|c|}{$\begin{array}{c}\text { Total } \\
(\mathrm{n} .=387)\end{array}$}} & \multirow{3}{*}{$\chi^{2}$} & \multirow{3}{*}{$P$ value } & \multirow{3}{*}{ df } \\
\hline & \multicolumn{2}{|c|}{$\begin{array}{c}\text { Physicians } \\
\text { (n. }=249)\end{array}$} & \multicolumn{2}{|c|}{$\begin{array}{c}\text { Nurses/dayas } \\
\text { (n. }=138)\end{array}$} & & & & & \\
\hline & No. & $\%$ & No. & $\%$ & No. & $\%$ & & & \\
\hline Bleeding & 70 & 28.1 & 48 & 34.8 & 118 & 30.5 & \multirow{5}{*}{$11.24 *$} & \multirow{5}{*}{$<0.05$} & \multirow{5}{*}{4} \\
\hline Infection & 65 & 26.1 & 41 & 29.7 & 106 & 27.4 & & & \\
\hline Pain & 47 & 18.9 & 32 & 23.2 & 79 & 20.4 & & & \\
\hline Shock & 40 & 16.1 & 10 & 7.2 & 50 & 12.9 & & & \\
\hline Injury to adjacent tissue & 27 & 10.8 & 7 & 5.1 & 34 & 8.8 & & & \\
\hline
\end{tabular}

* Statistically significant difference.

\section{Discussion}

Female genital mutilation, has received growing attention from governmental and international organizations and researchers over the last decades decade due to its impact on women's health ${ }^{(1,2)}$.

In the current study the prevalence of FGMamong secondary school girls was $53.7 \%$. This finding agree with study conducted by Tag-El-din et al. (2008) in Egypt who revealed that, the prevalence of FGC among school girls was $(50.3 \%)^{(8)}$. Also study conducted by Barakat and Mosleh (2012) in Egypt reported that, the prevalence of FGC among university students was $(50.9 \%)^{(15)}$. The current figure is lower than that reported in other studies ${ }^{(9,17)}$,and higher than that reported in other countries such as Nigeria $(2012)^{(18)}$ and eastern Ethiopia $(2009)^{(19)}$. Several factors may explain the discrepancy in the prevalence of FGM among the previous studies such as; research methods, sampling techniques, cultural differences, and religious practices of the various communities involved ${ }^{(20)}$.

Ethnicity is likely to explain higher FGM rates in rural areas ${ }^{(21)}$. In the current study, urban girls were less likely to be circumcised than rural girls, in agreement with others ${ }^{(15,17,22)}$. This may be due to the fact that the practice is deeply rooted in the culture and tradition of the rural areas than the urban areas.

In most countries, daughters of mothers who are more highly educated are less likely to have undergone FGM than daughters of mothers with little or no education ${ }^{(21)}$. In the current study, the findings revealed that, the parents with lower educational levels were the most likely to have submitted their daughters to FGM, in agreement with other studies ${ }^{(15,23,24)}$. With increasing highest level of education, the proportion of individuals who support the continuation of the practice decreased. This might be due to the fact that when education increases, awareness about the consequences of FGM increases leading to a decrease in the practice $^{(25)}$.

Concerning the economic status, girls living in the lowest economic levels were more likely to be circumcised than in other levels, in agreement with Egypt Demographic Health Survey findings $(2008)^{(9)}$.

The age at which FGM is performed on girls varies between countries and even from area to area within the same country. FGM is typically performed on young girls who are between 4 and 12 years old, however, the procedure may be carried out shortly after birth to sometime before the age of marriage ${ }^{(21)}$. In the current study, the mean age at the time of practice was significantly lower among rural residents than urban, in agreement with others studies ${ }^{(8,9,10)}$. The average age of FGM is getting lower so that it can be more easily hidden from authorities in countries where there may be laws against it. It is also possible that FGM is performed on younger girls because they are less able to resist ${ }^{(26)}$.

In Africa, FGM is usually carried out by traditional practitioners or lay persons. In Egypt, in the past, the majority of FGM procedures were performed by traditional midwives, called dayas. However, according to the Egypt Demographic Health Survey (1995), the number of procedures performed by medical practitioners (doctors, nurses or trained midwives) tripled to $55 \%$ with a concomitant drop in the use of dayas ${ }^{(21)}$.In the present study, the findings revealed that, the majority of FGM procedures in the urban areas $(71.8 \%)$ were performed by a physicians compared to $(59.3 .5 \%)$ in the rural areas, in agreement with others studies ${ }^{(8,9,15)}$. As a result of increasing health awareness about the health consequences associated with FGM, the parents may go to health practitioners instead of traditional excisers because they believe it will reduce the risk of harm ${ }^{(27)}$.

The procedure of FGMis usually performed at home, in unhygienic conditions, and usually without anesthesia, and might associated with increases in the risk of health consequences ${ }^{(17,26)}$. In the present study, the procedure of FGM was commonly performed at home, in agreement with others studies ${ }^{(8,10,17)}$.

Issued as a decree by the Egyptian Minister of Health in 1996, the ban prohibits all medical and nonmedical practitioners from performing FGM in either public or private facilities, except for medical reasons certified by the head of a hospital's obstetric department ${ }^{(15,28)}$. In the present study, the findings revealed that, more than three quarters of circumcised girls $(84.8 \%)$ in the rural areas were not submitted to medical examination before the procedure to find out if the girl was in need of circumcision or not, compared to $(67.3 \%)$ in the rural areas. This findings supported by Jacksonet al.(2003) who reported that, the medical examination represents the gold standard for assessing whether or not a girlin needs for circumcision ${ }^{(28)}$. 
A study conducted by Bjalkanderet al. (2012), revealed that, mothers, grandmothers and fathers are the main decision makers for girls undergoing FGM, with females representing two thirds of the reported decision makers ${ }^{(29)}$. The results of the present study revealed that, the mothers were the main decision-makers for the procedure of FGM $(62.8 \%)$, while the fathers played minor roles as decision-makers for the procedure $(37.2 \%)$, in agreement with other studies ${ }^{(8,30)}$. Other studies in Sierra Leone confirm our findings that the mother has a major role as instigator in the decision making for $\mathrm{FGM}^{(29,31)}$.

Adolescents living in rural areas have shown significantly higher levels of support for the continuation of FGM than their urban parts ${ }^{(32)}$. In the current study the results shows that, more than half of respondents in the urban area $(64.8 \%)$ were against continuation of the practice, compared to $(44.9 \%)$ in the rural area. Women that living in the urban areas, having a higher level of education/literacy, and those who were working, were more likely to support discontinuation of $\mathrm{FGM}^{(22)}$.

A study conducted by Tag-Eldin et al. (2008) in Egypt revealed that, about $53.9 \%$ of girls, said circumcision is not important and that it is an unhealthy and painful procedure, while $17.5 \%$ said that it is unnecessary for females and around $12 \%$ believed that there is no religious support for circumcision ${ }^{(8)}$. In the current study the results revealed that, the most common reasons against continuation of practice were; no religious support, painful and unhealthy procedure, unnecessary for girl, bad social habit and health consequences related to it, in agreement with other studies ${ }^{(8,9,23,35)}$.

FGM is performed for reasons that include; sexual (to control or reduce female sexuality), sociological (as an initiation for girls into womanhood, social integration and the maintenance of social cohesion), hygiene and aesthetic reasons (due to a belief that the female genitalia are dirty and unsightly), health (in the belief that it enhances fertility and child survival) and for religious reasons-due to the mistaken belief that it is a religious requirement ${ }^{(33)}$. The girls in the current study were asked for reasons support the practice of FGM and they answered that circumcision is an important religious requirement, cultural and social traditional, restraining sexual desire, cleanliness for girls, chastity and evidence of feminist, in agreement with other studies ${ }^{(8,9,20)}$. Other studies in Africa concluded that the most significant factors associated with the acceptance of FGM were religion, tradition and social pressure, as reported in Egypt and Sudan ${ }^{(34,35)}$, while ethnicity and to control female sexuality were the most significant social predictor of FGM in Nigeria ${ }^{(36)}$. Both ethnicity and religion were the strongest predictors of FGM in the United Republic of Tanzania ${ }^{(37)}$.

The performance of FGM has an impact on the physical, psychological, sexual and reproductive health of women, and may lead to severe deterioration in their quality of life ${ }^{(38,39)}$. In the current study, the most common post-practice complication were; bleeding, infection, pain, shock and injury to adjacent tissues, in agreement with others studies ${ }^{(4,8,40)}$. Recently, many articles have reported post-practice complications (early and late) such as severe pain, bleeding, incontinence, infections, mental health problems, sexual problems, primary infertility and difficult labour with high episiotomy rate. In addition, the repetitive use of the same instruments on several girls without sterilization can cause the spread of HIV and Hepatitis B and $\mathrm{C}^{(34,40)}$. The findings of the present study revealed that, the post-practice complications were more prevalent when the circumcision was performed by nurses or dayas, in agreement with other studies ${ }^{(5,41)}$.

\section{Conclusions}

The current study revealed that, FGM is still widespread among school girls in Egypt. Factors associated with FGM included; rural residence, lower educational levels of the both parents, and those living in lowest economic levels. There was a considerable support for the continuation of the practice particularly in the rural areas.The most common reasons under continuation of the practice were; religious requirement, cultural and social traditional, restraining sexual desire, cleanliness for girls, chastity and evidence of feminist. The postpractice complication were; bleeding, infection, pain, shock and injury to adjacent tissues. The post-practice complications were more prevalent when the procedure of FGM was performed by nurses or dayas

\section{Acknowledgment}

I would like to thank all school girls who shared in the study, the educational authorities in the region and everyone who helped me to accomplish this work.

Conflict of interest : non

\section{References}

[1]. Shell-Duncan B,Ylva H. Female circumcision in Africa: Dimensions of the practice and debates. In Female Circumcision in Africa: Culture, Controversy, and Change. Eds. Bettina Shell-Duncan and YlvaHernlund. Boulder, CO: LyneReinner,2000; p. 1-40.

[2]. Schroeder P. Female genital mutilation; a form of child abuse. N Engl J Med. 1994 Sep 15; 331(11): 739-40.

[3]. World Health Organization. Eliminating Female Genital Mutilation: An interagency statement. Geneva, 2008. http://www.unfpa.org/webdav/site/global/shared/documents/publications/2008/ eliminating_fgm.pdf. Accessed March 7, 2009.)

[4]. UNICEF. Female genital mutilation/cutting. A statistical

2005.http://www.childinfo.org/files/fgmc_U83FGM_9_web_Finalversionprinted.pdf 
[5]. World Health Organization. Global strategy to stop health-care providers from performing female genital mutilation UNAIDS, UNDP, UNFPA, UNICEF, UNHCR, UNIFEM, WHO, FIGO, ICN, IOM, WCPT, WMA, MWIA, 2010.http://whqlibdoc.who.int/hq/2010/WHO_RHR_10.9_eng.pdf

[6]. Argaw A, Michael K.W, and Fisseha N. Prevalence of female genital mutilation and attitude of mothers towards it in serbo town. Ethiop J Health Sci,2002; 12(2):; 59-68.

[7]. WHO. Men's and women's perceptions of the relationship between female genital mutilation and women sexuality in three communities in Egypt, 2010.http://whqlibdoc.who.int/hq/2010/ WHO RHR H RP 10.17 eng.pdf (accessed 20/1/1012).

[8]. Tag-Eldin M A, Gadallah M A, Al-Tayeb M N, Abdel-Aty M, Mansour E, and Sallem M. Prevalence of female genital cutting among Egyptian girls. Bulletin of the World Health Organization, 2008; April 2008, 86 (4)

[9]. El-Zanaty F, Way A. Egypt Demographic and Health Survey. National Population Council; Ministry of Health and Population, 2009. http://www.measuredhs.com/pubs/pdf/FR220/FR 220.pdf (accessed 20/1/2012).

[10]. Zayed AA, Ali AA. Abusing female children by circumcision is continued in Egypt. J Forensic Leg Med 2012; 19(4):196-200. http://www.ncbi.nlm.nih.gov/pubmed/22520370

[11]. Emam E A, EL-Maghawri A M, and Labeeb S A. Cultural Awareness about Female Genital Mutilation among Female Employees of Minia University. Journal of American Science 2011;7(4):611-617. (ISSN: 1545-1003). http://www.americanscience.org.

[12]. Toubia N F, Sharief E H. Female genital mutilation: have we made progress? Int J GynaecolObstet, 2003; 82:251-61.

[13]. World Health Organization. New study shows female genital mutilation exposes women and babies to significant risk at childbirth. Press release, 2006. Retrieved on 2006-10-02.

[14]. U.S. Department of State. Report on Female Genital Mutilation (FGM) or Female Genital Cutting (FGC) in Egypt, 2001.http://2001-2009.state.gov/g/wi/rls/rep/crfgm/10096.htm

[15]. Barakat A A, Mosleh H. Prevalence of Female Genital Cutting among University Students in Egypt. Journal of American Science 2012; 8 (11) http://www.jofamericanscience.org.

[16]. Fahmy S, El-Sherbini A F. Determining simple parameters for social classifications for health reaserch. Bulletine of the High Institute of Public Health, 1983, 13:95-108

[17]. Hassanin IM, Saleh R, Bedaiwy AA, Peterson RS, Bedaiwy MA. Prevalence of female genital cutting in Upper Egypt: 6 years after enforcement of prohibition law. Reprod Biomed Online, 2008;16 Suppl 1:27-31.

[18]. Iliyasu Z, Abubakar IS, Galadanci HS, Haruna F, Aliyu MH. Predictors of female genital cutting among university students in northern Nigeria. J ObstetGynaecol, 2012; 32 (4): 387-392.

[19]. Mitike G, Deressa W. Prevalence and associated factors of female genital mutilation among Somali refugees in eastern Ethiopia: a cross-sectional study. BMC Public Health, 2009; 9:264 http://www.biomedcentral.com/1471-2458/9/264

[20]. Yirga W S, Kassa N A, Gebremichael M W and Aro A R. Female genital mutilation: prevalence, perceptions and effect on women's health in Kersa district of Ethiopia. International Journal of Women's Health, 2012; 4:4554.http://www.dovepress.com/female-genital-mutilation-prevalence-perceptions-and-effect-on-women39-peer-reviewed-articleIJWH-recommendation 1

[21]. El-Zanaty F, Hussein EM, Shawky GA, Way AA, Kishor S. 16. Egypt demographic and health survey 1995. Calverton, MD: National Population Council and Macro International.

[22]. Dalal K, Lawoko S, Jansson B. Women's attitudes towards discontinuation of female genital mutilation in Egypt. J Inj Violence Res, 2010; 2(1): 41-7. doi: 10.5249/jivr.v2i1.33 journal homepage : http://www.jivresearch.org

[23]. Refaat AH, Dandash KF, Lotfy G, and Eyada M.Attitudes of medical students towards female genital mutilation. J Sex Marital Ther, 2001; 27:589-91.

[24]. Aigbodion A I, Imhonde H O, and Aluede O. A Pilot Study of the Attitude of Nigerian University Students Towards Female Genital Mutilation. Anthropologist, 2004; 6(4): 247-252.

[25]. Abebe G M, Hailemariam A, Belachew T, Michael K W, Lindstrom D. Support For The Continuation Of Female Genital Mutilation Among Adolescents In Jimma Zone, Southwest Ethiopia. Ethiop J Health Sci, 2009. Vol.19 No.2

[26]. Bacquet-Walsh C, Jordan S, Moneti F. Female Genital Cutting. Frequently asked questions. U.S. Department of Health and Human Services, Office on Women's Health, 2010.http://www.womenshealth.gov/publications/our-publications/fact-sheet/female-genitalcutting.

[27]. Shell-Duncan B. The medicalization of female "circumcision": harm reduction or promotion of a dangerous practice? Social Science \& Medicine, 2001; 52(7):1013-28.

[28]. Jackson E F, Akweongo P, Sakeah E, Hodgson A, Asuru R, Phillips J F. Inconsistent Reporting of Female Genital Cutting Status in Northern Ghana: Explanatory Factors and Analytical Consequences. Studies In Family Planning, 2003; 34[3]: 200-210.

[29]. Bjalkander O, Leigh B, Harman G, Bergström S, and Lars Almroth L. Female Genital Mutilation in Sierra Leone: who are the decision makers?. Afr J Reprod Health 2012; 16[4]: 119-131).

[30]. Behrendt, A. Female Genital Cutting in the Moyamba and Bombali Districts of Sierra Leone. Final Report. Dakar: Plan West Africa Regional Office, 2005.

[31]. Kallon I, Dundes L. The Cultural Context of the Sierra Leonean Mende Woman as Patient. J Transcultural Nursing 2010; 21(3):228 -236 .

[32]. Abebe GM, Assefa H, Tefera B, Kifle WM, David L. Support for the continuation of female genital mutilation among adolescents in Jimma Zone, Southwest Ethiopia. Ethiop J Health Sci. 2009. Vol.19 No.2

[33]. Hedayat KM, Roya P. Issues in Islamic Biomedical Ethics: a Primer for the Pediatrician 2006; 108(4):965-71.

[34]. Almroth L, Almroth-Bergren V, Hassanein OM, El-Hadi N, Al Said SS,Hasaan SS, et al. A community based study on the change of practice of female genital mutilation in a Sudanese village. Int J GynaecolObstet 2001;74:179-85. PMID:11502298 doi:10.1016/S0020-7292(01)00392-7

[35]. Allam MF, de Irala-Estevez J, Fernandez-Crehuet-Navajas R, Serrano del, Castillo A, Hoashi JS, et al. Factors associated with the condoning of female genital mutilation among university students. Public Health 2001;115:350-5. PMID:11593445 doi:10.1016/S0033-3506(01)00474-7

[36]. Snow RC, Slanger TE, Okonofua FE, Oronsaya F, Wacker J. Female genital cutting in southern urban and peri-urban Nigeria - Selfreported validity, social determinants and secular trend. Trop Med Int Health 2002;7:91-100. PMID:11851959 doi:10.1046/j.13653156.2002.00829.x

[37]. Klouman E, Manogi R, Klepp KI. Self-reported and observed female genital cutting in rural Tanzania associated demographic factors, HIV and sexually transmitted infections. Trop Med IntHealt 2005;10:105-15. doi:10.1111/j.1365-3156.2004.01350.x

[38]. Craft N. Women's health. Life span: conception to adolescence. BMJ, 1997; 315:1227-30.

[39]. The Royal College of Midwives. Female Genital Mutilation (Female Circumcision). In Position Paper no 21 London: The Royal College of Midwives, 1998. 
[40]. Elgaali M, Strevens H, Mardh PA. Female genital mutilation an exported medical hazard. Eur J ContraceptReprod Health Care 2005;10:93-7.

[41]. Shell-Duncan B. The medicalization of female "circumcision": harm reduction or promotion of a dangerous practice? Social Science and Medicine 2001; 52(7):1013-1028.

[42]. Pearce A J and Bewley S. Medicalization of female genital mutilation. Harm reduction or unethical?. Obstetrics, Gynaecology and Reproductive Medicine; 2014. Vol. 24. Issue 1. Page 29-30 